\title{
PM アルミ合金の粉末鍛造
}

大梘 真人, 由利 浩一

川瀬 欣也, 河野通

三菱マテリアル件中央研究所, $\mathbf{T} 330$ 大宮市北袋町1-297.

\section{Powder Forging Processing of Rapidly Solidified Aluminum Alloy Powders}

\author{
Masato Otsuki, Koichi Yuri
}

Kinya Kawase and Tohru Kohno

Gentral Research Institute, Mitsubishi Materials Corp., 1-297 Kitabukuro-cho, Omiya 330.

Received June 21, 1994

Powder forging processing of rapidly solidified aluminum alloys has benefits of excellent material properties attained by rapid solidification process and of high production efficiency of PM parts. In this study, powder forged Al-Si and Al-Fe base alloys were prepared using double action forging press and the mechanical properties were examined. In this process, it is possible to conduct two steps of compaction and deformation of preforms in one shot. It was confirmed that the mechanical properties of Al-Fe base alloy powder forged by double action forging press has good mechanical properties as of the extrusion. The double action forging give good metallurgical bonding between powders by efficient dispersion of surface oxides even the amount of plastic deformation is relatively low.

\section{1 緒言}

急冷凝固アルミ合金粉末材は軽量かつ各種 機械的, 物理的特性に優れ, 種々の機械部品 への適用が進められているが，この為の複雑 形状部品への成形固化方法として，製造コス トおよび材料特性の両面から粉末鍛造法が有 望視されている1-2). 粉末鍛造プロセスによ り，原料粉末を最小限の熱履歴により成形固
化し，急冷凝固組織を維持しつつその優れた 材料特性を引き出しながら, 従来の焼結機械 部品同様の高い生産性にて複雑形状部品を生 産することが可能である。本プロセスに於い ては粉末の急冷凝固組織を維持しながら, 緻 密化, 粉末間の結合付与, 製品形状の付与を 行う為に, ワーク温度, 加圧圧力, 塑性変形 量, 変形モ一ド等の適切な鍛造方案, 条件の 
Table 12) Mechanical properties of double forged and extruded $\mathrm{Al}-25 \mathrm{Si}-2.5 \mathrm{Cu}-1 \mathrm{Mg}-1 \mathrm{Fe}$ alloy powder.

\begin{tabular}{|c|c|c|c|c|c|c|}
\hline Process & $\begin{array}{c}\text { Hardness } \\
\text { HRB }\end{array}$ & $\begin{array}{l}\text { UTS } \\
\mathrm{MPa}\end{array}$ & $\begin{array}{l}\text { YS } \\
\mathrm{MPa}\end{array}$ & $\begin{array}{c}\text { Elong } \\
\%\end{array}$ & $\begin{array}{l}\text { F. S. } \\
\text { MPa }\end{array}$ & $\begin{array}{l}\text { S. S. } \\
\text { J/cm2 }\end{array}$ \\
\hline & c) 87 & 461 & 372 & 1.0 & 259 & 3.5 \\
\hline xtrusion & 85 & 451 & 421 & 0.8 & 221 & 4.1 \\
\hline
\end{tabular}

a) : Fatigue Strength, Rotation bend, $\mathrm{N}=10^{7}$.

b) : Sharpy impact strength .

c) : Reduction ratio $=30 \%$.

d) : Extrution ratio $=1: 25$.

選定が必要となる，著者らは今までに種々の 粉末鍛造法の検討を進めており，この中で予 備成形体を熱間圧縮（coining）し，強固なプリ フォームを作製した後これを熱間鍛造 (forging) することにより高い材料歩留で健全 な複雑形状部品を製造することが可能な二段 鍛造法を開発している2-3)，本手法で得られる $\mathrm{Al}-\mathrm{Si}$ 系合金の材料特性の例をTable 1 に示す.

$\mathrm{Al}-\mathrm{Si}$ 系合金等の高温での変形抵抗が比較的小 さい合金粉末では，鍛造温度，圧力を適切に 選定することにより coiningのみの一段鍛造でも 健全な製品を得ることが可能となっている4) が,この場合複雑形状の付与は難しい.

方, Al-Fe系耐熱合金で代表される高温変形抵 抗の大きい粉末に対しては十分な塑性変形を 施さないと製品各部での健全な粉末間の結合 が得られず，複数回の鍛造が必要となる3)。そ こで本研究では急冷凝固アルミ合金粉末鍛造 品の材料特性, 形状付与性, 生産性向上を目 的として，Al-Si系耐摩耗合金およびAl-Fe系耐 熱合金を対象に複動鍛造を用いた成形固化プ ロセスについて検討した結果を報告する。

\section{2 試料および実験方法}

実験方法としてはFig. 1 に示す様に, 窒素ガ スアトマイズ法にて作製したAl-25Si系および $\mathrm{Al}-10 \mathrm{Fe}$ 系急冷凝固アルミ合金粉末を原料と し，室温金型成形によりプリフォームを作製

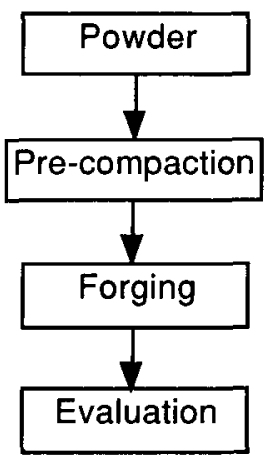

N2 gas atomized powder

$\mathrm{Al}-25 \mathrm{Si}-3 \mathrm{Cu}-1 \mathrm{Mg}-1 \mathrm{Fe}$

Al-10Fe-8Si-2Cr

Rigid die at RT

Double action press

Die temp. $350 \sim 450^{\circ} \mathrm{C}$

Tensile test

SEM fractography

Fig. 1 Sample preparation steps.

し，これをこれを $450 〜 500^{\circ} \mathrm{C} に$ 予備加熱した 後，二軸鍛造プレスを用いた熱間鉔造に於い て，圧縮緻密化とこれに引き続くボス形状あ るいはリブ形状を付与する塑性加工を連続し て行い, 鍛造体の形状付与性および材料特性

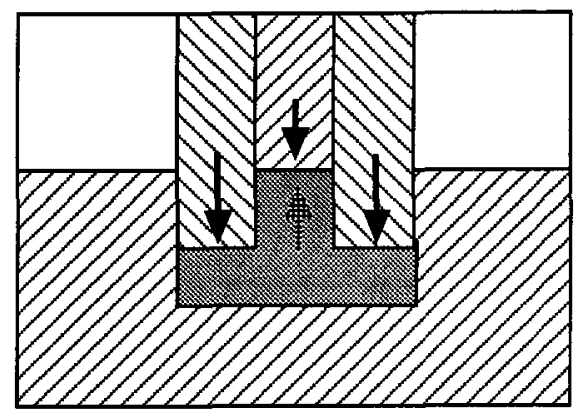

(a)

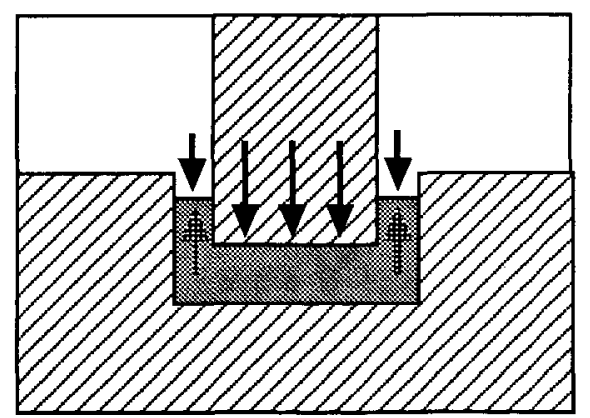

(b)

$\downarrow$ : forging load, : deformation flow

: die or punch, 1 : powder

Fig. 2 Schematics of double action powder forging processing to consolidate (a) a disk with boss and (b) a block with rib. 
を評価した。また比較として粉末押出材も作 製評価した. Fig. 2 に本実験で用いた複動鍛造 の概念図を示す。リブ付ブロック鍛造体は, 角柱状ブロックの長手方向の両端にリブを付 与した形状のもので, 引張り試験はこの角柱 部分中央より，その長手方向を軸方向とした 試験片を切り出し評価した.

\section{3 実験結果および考察}

Photo. 1にAl-Si系粉末二二軸鍛造プレスを 用いたボス付き円盤の外観写真を示す。二軸
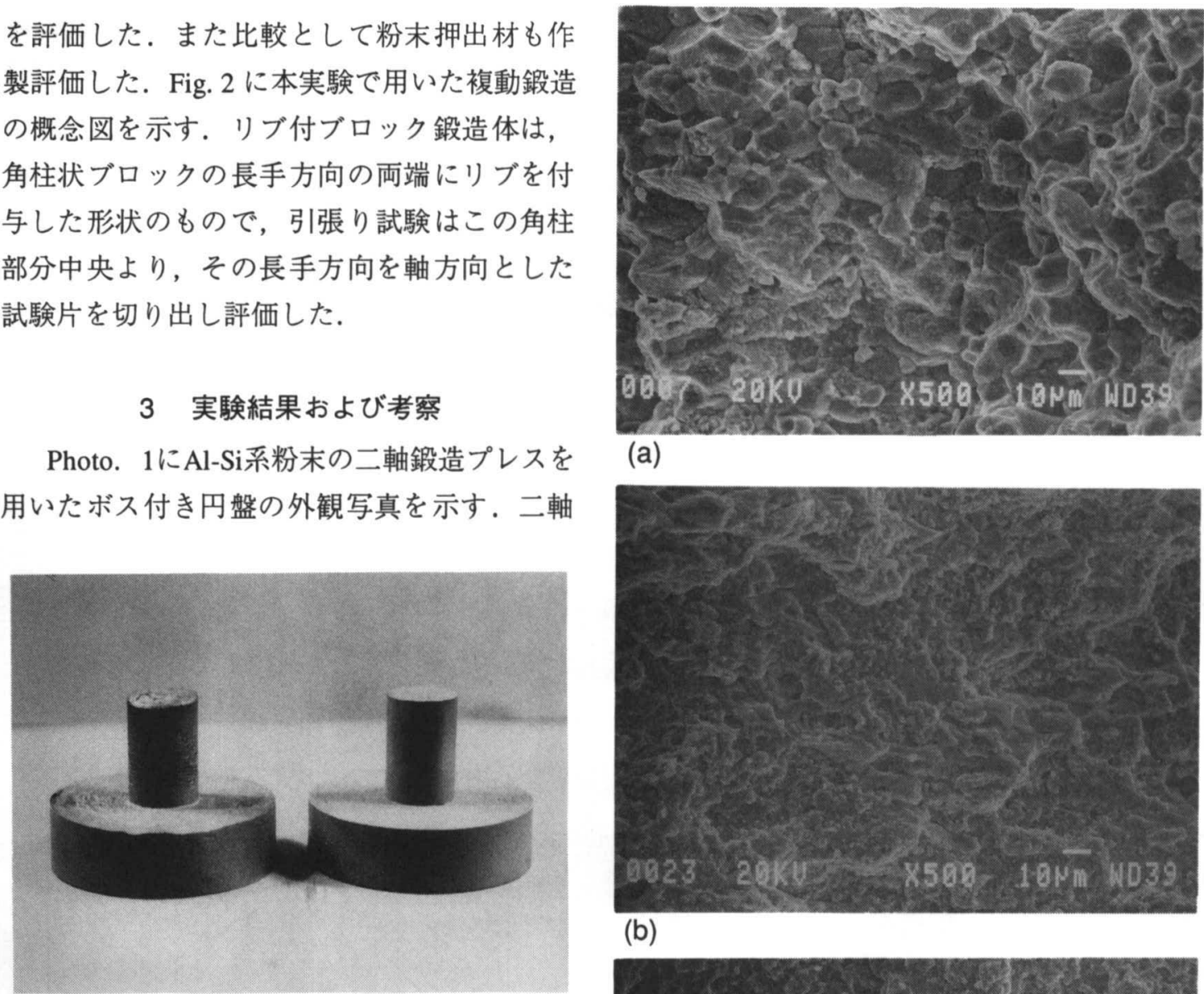

(a)

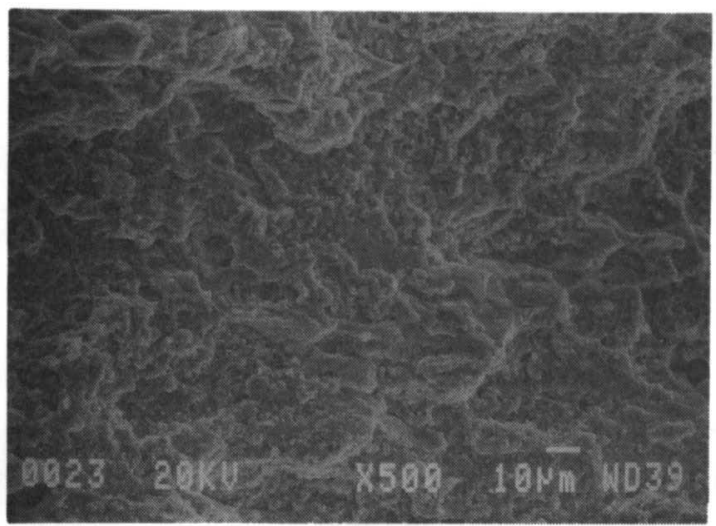

(b)

Photo. 15) Outlook of forged Al-Si base alloy powder by double action forging (a) with and (b) without back pressure.

鍛造プレスを用いることにより，一回の鍛造 工程中に緻密化と塑性加工という, 内容的に は二段の工程を連続して行うことが可能であ り，これにより複雑形状部品を製造すること

Table 2 Mechanical properties of $\mathrm{Al}-10 \mathrm{Fe}-8 \mathrm{Si}-2 \mathrm{Cr}$ alloy powder forged by double action press and extruded.

\begin{tabular}{|c|c|c|c|c|}
\hline \multicolumn{3}{|c|}{ Process Die temp.Hardness } & \multirow{2}{*}{$\begin{array}{l}\text { UTS } \\
\text { MPa }\end{array}$} & \multirow{2}{*}{$\begin{array}{c}\text { Elong. } \\
\%\end{array}$} \\
\hline & ${ }^{\circ} \mathrm{C}$ & HRB & & \\
\hline Forging ${ }^{\text {a) }}$ & 350 & 84 & 309 & 0.2 \\
\hline Forging a) & 450 & 84 & 450 & 1.3 \\
\hline Extrusionb) & 490 & 84 & 486 & 1.4 \\
\hline
\end{tabular}

a) : Reduction ratio $=30 \%$.

b) : Extrution ratio=1:25.

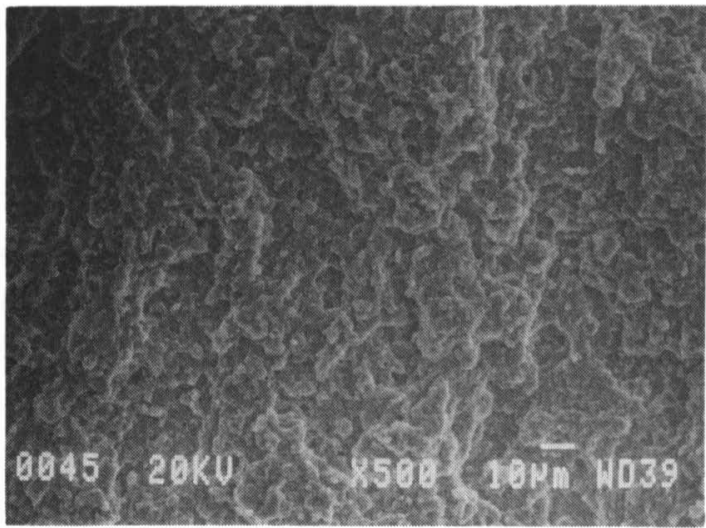

(c)

Photo. 2 SEM fractographs of powder Al-10Fe-8Si$2 \mathrm{Cr}$ alloy consolidated by double action forging in die temp. of (a) $350^{\circ} \mathrm{C}$, (b) $450^{\circ} \mathrm{C}$ and (c) by extrusion.

が可能である5).

Table 2 にはAl-Fe系粉末のリブ付ブロック鍛 造体の材料特性を示す. 高温変形抵抗の大き いAl-Fe系粉末に於いても, 鍛造金型温度をプ 
リフォーム温度と同じ程度にする，即ち恒温 複動鍛造に於いては押出材に近い材料特性が 得られた. Photo. 2 に各試料の引張破断面の SEM写真を示す。金型温度の低い場合の鍛造 材の破面は旧粉末粒界から成っているのに対 し，恒温複動鉔造を施した試験片の破面は押 出材のそれと同様，粉末内部での破断が多 く，粉末間の結合が十分形成されていること が判る。本実験ではリブ部の体積から算出さ れる鍛造压下率は約 $30 \%$ と低いが, 複動鍛造 に於いては加圧下で粉末に塑性変形を与える 為, 比較的少ない加工量でも效率的な粉末表 面酸化被膜の破壊分散とこれによる健全な粉 末間の結合が形成されることにより良好な材 料特性が得られたものと考えられる。

\section{4 結 論}

1. 二軸鍛造プレスを用いることにより一回 の鍛造工程中に緻密化と塑性加工という，内 容的には二段の工程を連続して行うことが可 能でありこれにより複雑形状部品を短い工 程で製造することが可能である.

2. 高温変形抵抗の大きいAl-Fe系粉末に於い
ても複動銓造により押出材に近い材料特性が 得られている。

3. 複動鍛造に於いては加圧下で粉末に塑性 変形を与える為, 比較的少ない加工量でも効 率的な粉末表面酸化被膜の破壊分散とこれに よる健全な粉末間の結合が形成されていると 考えられる。

\section{文献}

1) D. Raybould : Dispersion Strengthened Aluminum Alloys, The Minerals, Metals, and Materials Society (1988) 199.

2) 大槻真人，河野通：粉体および粉末治金 37 (1991) 513.

3) 梯伸一郎, 大槻真人, 河野通 : 粉体およ び粉末治金35 (1988) p 673.

4) 川瀬欣也, 大槻真人, 河野通, 森本耕一郎： 粉体粉末治金協会平成3年度春季大会概要 (1991) 258.

5) K. Kawase, M. Otsuki, T. Kohno,

K. Morimoto, M. Kobayashi : Proceedings of 1993 Powder Metallurgy World Congress (1993) 899. 